\title{
Edco-Tourism: A Coastal Management Program to Improve Social Economics
}

\author{
Arsi Rakhmanissazly ${ }^{1 *}$, Anggun Intan Permatasari ${ }^{1,2}$ and Ely Chandra Peranginangin ${ }^{1}$ \\ ${ }^{1}$ Department of Legal \& Relations, PT PERTAMINA EP Asset 1 Pangkalan Susu Field, Indonesia
}

${ }^{2}$ Department of Social Development and Welfare, Gadjah Mada University, Indonesia

Submission: April 06, 2018; Published: April 12, 2018

*Corresponding author: Arsi Rakhmanissazly, Department of Legal \& Relations, PT PERTAMINA EP Asset 1 Pangkalan Susu Field, Langkat, North Sumatera, Indonesia 20858, Email: arsi.rakhmanissazly@pertamina.com

\begin{abstract}
Coastal erosion is a natural process even in pristine environments. Mangrove is tropical coastal vegetation that may prevent and controls the soil erosion. As the longest coastline country in the world, Indonesia has great ecological potential of mangrove. Sadly, according to Food and Agriculture Organization (FAO) since 2007 Indonesia has lost 40\% of mangrove forest because of deforestation for the last three decades. Langkat regency placed as the most destructive mangrove forests in North Sumatera about 25\% of total area hectares due to severe damage. Green Belt Lubuk Kertang is a Corporate Social Responsibility (CSR) program held by PT PERTAMINA EP Asset 1 Pangkalan Susu Field (PEP) aims to overcome deforestation problem by implementing the concept of edcotourism mangrove. Edcotourism is a concept that combines educational and environmental as the basis of local tourism management. By implementing this concept PEP may create multiplier effect not only by saving environmental issues but also socio economical for local communities. This study shows the impacts of the program for some aspects. By using Shannon-Wienner indicator shows the biodiversity index has increased since the program began three years ago. Not only biodiversity number but also group's income of local community increase obtained from the retributions. Furthermore, this program is social investment for PEP to engage company-community relations during operational by gaining license to operate. PEP attempt to implement integrated coastal zone management to balance environmental, technical, socio-economic and recreational objectives, into an eco - coastal sustainable system.
\end{abstract}

Keyword: Corporate social responsibility; Coastal management; Edco-tourism; Environment; Socio-economic; Sustainable development

\section{Introduction}

As the biggest archipelago's country in the world, Indonesia has more than $90.000 \mathrm{~km}$ coastlines with enormous undiscovered of coastal potential. About 14 millions of Indonesia's people or at least $7,5 \%$ from total rely their livelihoods in coastal areas [1]. According to Sorensen and McCreary in Institutional Arrangement for Managing Coastal Resources and Environments, coastal zone is the borders where two main environments, the land and the water, elaborated. This definition is in line with UU No 27/2007 about Coastal and Small Islands Management. The supply of nutrients from the mainland through river and surface water makes the coastal area as a complex nature ecosystem. One of the ecosystems is mangrove that performs as production, protection and preservation area.

About 3 million hectares of mangrove forest grow along Indonesia's coastline. This is 23 percent of all mangrove ecosystems in the world [2]. Ecologically, Mangroves perform several functions such as inundation control, protection from erosion, storm, floods, and wave damage, recreation/ tourism, and generate tangible goods (such as fishes, shellfishes and other forest products). They possess distinct ecological attributes at multiple levels of organization such as site or stand, ecosystem and landscape levels [3]. Mangroves create double impact for the environment, as below the water as breeding and nursing grounds for fish and marine species, as above the water the mangrove trees and canopy serves as a habitat for birds, insects, mammals and reptiles also create economic value by community surround.

Unfortunately, over the past three decades, according to FAO (Food and Agriculture Organization) Indonesia has lost 40 percents of its mangroves. caused by the deforestation, conversion of mangroves area into ponds, settlements, industries and plantations. This means Indonesia has the fastest rate of mangrove destruction in the world [4]. Mangrove deforestations in Indonesia result in a loss of 190 million metric tonnes of $\mathrm{CO}_{2}$ annually. This accounts for 20 percents of land-use emissions in Indonesia [5] where emissions are estimated to be 700 million metric tonnes of $\mathrm{CO}_{2}$-eq [6].

This problem also happens in Lubuk Kertang, Langkat Regency, North Sumatera. In Early 2000s, there are about 80 hectares of mangroves converted into palm oil which made 
the fishermen loss their livelihoods. About only 25 percents of mangrove forest in Langkat categorized in good condition and the other $75 \%$ are damaged and rehabilitation phase [7]. It made Langkat as the most destructive mangroves forest in North Sumatera. As a company which has main working area in Langkat, PT PERTAMINA EP Asset 1 Pangkalan Susu Field (PERTAMINA EP) consequently designed some strategic programs to answer the problems of the society by utilizing some local potentials people barely realized. Green Belt Lubuk Kertang is one of Corporate Social Responsibility program held by PERTAMINA EP which aim to overcome deforestation issues by implementing Edco-tourism Mangrove concept. This concept is not only to promote mangroves tourism; but also to make positive and direct contribution between visitors and the local mangrove guardian community (named 'MEKAR').

The combination of triple bottom of CSR (people-planetprofit) mixed into a strategic coastal management program. PERTAMINA EP realizes that being a part of the community may become social investment for the company in the future. PERTAMINA EP sees the problem of land converting will harm the community, coastal ecosystem, natural environment and also indirectly may become as obstacles for the operation of PERTAMINA EP. By implementing this program, PERTAMINA EP creates multiplier effects which improve community in economical and environment benefits. Intangible benefits of mangrove ecosystems include social and cultural functions. Mangrove forests support religious and spiritual values, as well as recreational and aesthetic values for edcotourism [8].

\section{Coastal Management Program: Edco-tourism Green Belt Lubuk Kertang}

Coastal management is a coordinated strategy to undertake coastal problem and emerging issues such land erosion, public welfare, nature resources and also socio-cultural to minimize the negative impacts and assist coastal society to preserve the environment and create sustainable living based on coastal zone. On the other hand, CSR has been defined in many different ways. At bottom, it refers to companies integrating "social and environmental concerns in their business operations and in their interaction with their stakeholders on a voluntary basis (...) not only fulfilling legal expectations but also going beyond compliance [9]. Green Belt Lubuk Kertang is PERTAMINA EP's social strategy addressing deforestation issues. PERTAMINA EP elaborates the concept of coastal management with CSR itself. Developing the coastal management system in this program by cooperate not only with the community but also government agencies. (Figure 1)
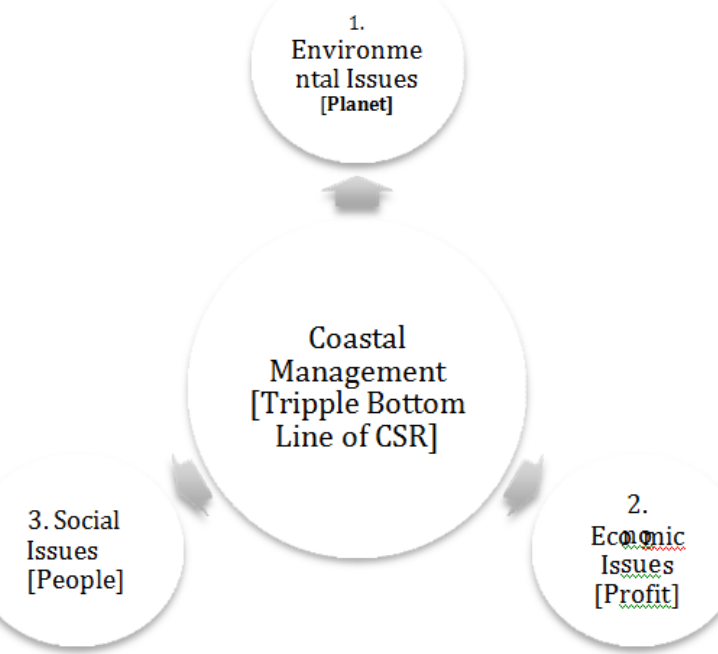

Figure 1: Correlation between Coastal Management and Triple Bottom Line of CSR.

There are similarities between the basic concept of CSR and coastal management following elements (Figure 2). Through CSR program, PERTAMINA EP takes the initiatives to implement community development strategy based on local wisdom and its potential to achieve the well-being of local communities. Basically, there are three main points that PERTAMINA EP concerns: (i) nature conservation, (ii) ecological education and (iii) economic improvement. Corporate social responsibility (CSR) program can become a source of tremendous social progress, as the business applies its considerable resources, expertise and insights to activities that benefit society [10].

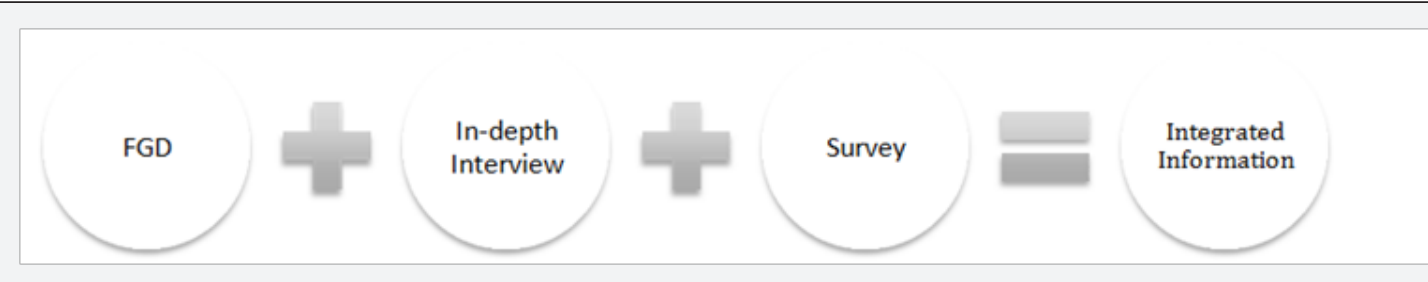

Figure 2: Social Mapping Formed.

\section{What is Edco-tourism?}

The Edco-tourism (education in eco tourism) concept basically based on potential tourism resources. According to The International Ecotourism Society (TIES: 2000), "Ecotourism is not only a tourist, but also a responsible natural tourism trip by conserving the environment and improving the welfare of local communities." PERTAMINA EP acquaint the interactive learning conservation for visitors in participating planting mangrove seeds and cultivation of natural ponds. Not only educate but also preserve mangrove vegetation the multiplier effects from the implementation of this program. 


\section{Methodology}

Social mapping defined as society description systemic processes with conduct data collection and society's information including profiling and social problem in the specific area. According to Netting, Kettner and McMurtry (1993) social mapping can also defined as social profiling. Social mapping is one of many approaches in community development as
Twelvetrees [11] said that social mapping is the process of assisting ordinary people to improve their own communities by undertaking collective actions [12]. We're using social mapping research as our based document before creating strategic plan (Figure 3). As the result of social mapping and needs assessment PERTAMINA EP will get the recommendation program which we use as groundwork of our CSR program in our main working area (Figure 4).

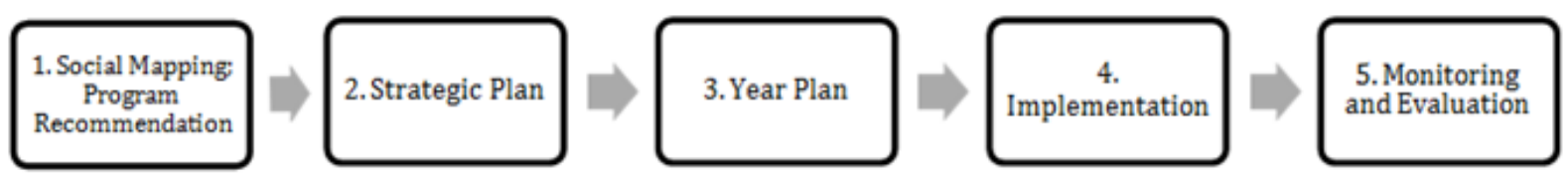

Figure 3: Process of CSR Program.

\section{Biodiveristy Index in Mangrove Conservation Area}

= Paluh Tabuhan Timur $\equiv$ Lubuk Kertang

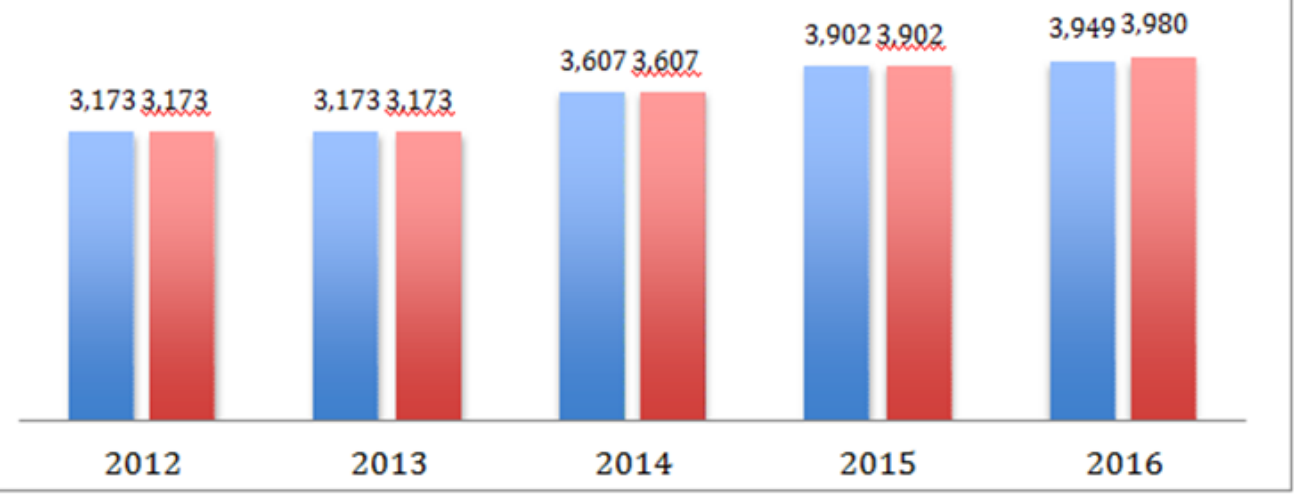

Figure 4: Biodiversity Index in Mangrove Conservation Area.

\section{Method of Effects Measurements}

The implementation of Edco-tourism program creates multiplier effects that involve three main aspects.

\section{Environment effects}

Some theories and approaches are used to measure environmental effects. We divided environment category into three main aspects; mangrove, local fauna and the whole conservation area. This research also used as our biodiversity report that describe how PERTAMINA EP practice to protecting environment issues during operational [13].

\section{Economy effects}

Using quantitative approach by collecting visitors data each month to see total visitors and the revenue that MEKAR get from managing the program. The visitors and revenue graphic used to monitor and evaluate the program to develop the next development strategy.

\section{Social Effects}

Table 1: Classification of Effects Measurements Method.

\begin{tabular}{|c|c|c|c|c|}
\hline No & Effects Category & Indicator & Method & Output \\
\hline 1 & Environment & $\begin{array}{c}\text { Mangrove vegetation } \\
\text { inventory }\end{array}$ & Systemic Cluster Analisis & Shannon Wienner Index \\
\hline & & Reptile and Aves Inventory & Count Conservation Analysis & Shannon Wienner Index \\
\hline & & Insects Inventory & Systemic Cluster Analisis & Shannon Wienner Index \\
\hline
\end{tabular}


Recent Advances in Petrochemical Science

\begin{tabular}{|c|c|c|c|c|}
\hline & & Life below water Inventory & Systemik Trap Identification & Shannon Wienner Index \\
\hline & & Conservation Area & GPS tematic overlay map & Biodiveristy index \\
\hline 2 & Economy & Visitors & Amount of visitors & Visitors graphic \\
\hline 3 & & Income & Financial report & Financial graphic \\
\hline
\end{tabular}

Public Satisfaction Index (IKM) is data and information derived from costumer satisfaction, in this case community, using two research approaches. Community survey for the quantitative measurements and in-depth interview for the qualitative. This

method considering community opinion as database to compare the expectations and needs about the existing CSR program. To measure these aspects, we used different method and indicators as classified in Table 1.

Result

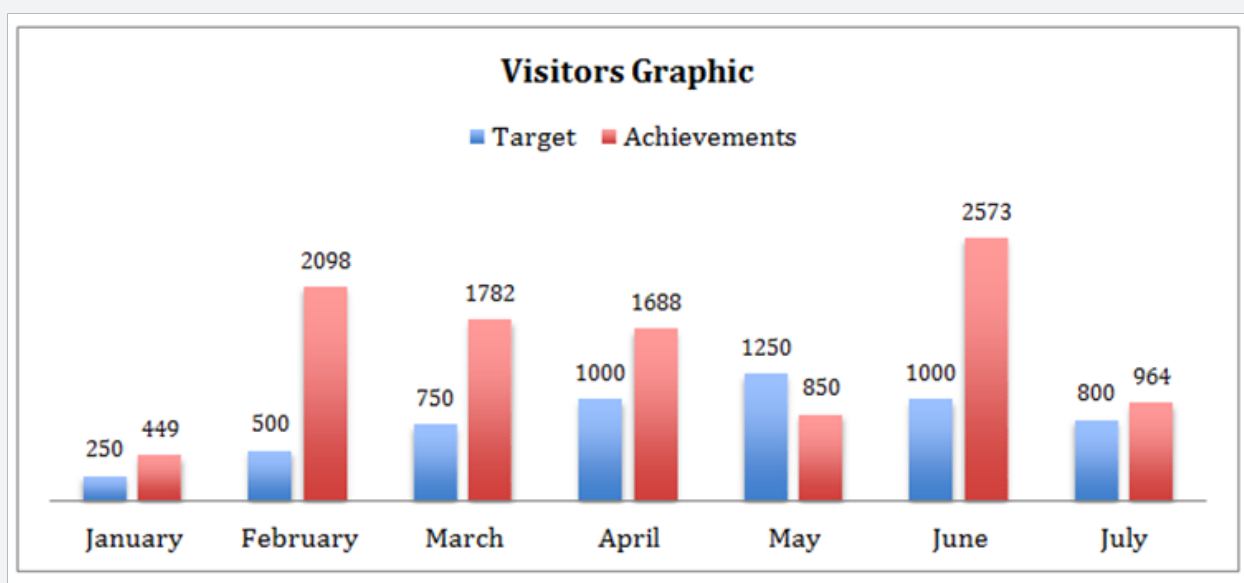

Figure 5: Visitors Graphic.

At first, Green Belt Lubuk Kertang program is expected to help restore critical land due to deforestation. Programs that initially to save the environment only now develop and creating multiplier effects for the economic and social conditions of the community. This may give the community chance to improve their socio economic by preserving the nature and their coastal local potential for living. PERTAMINA EP also trying to improve the relationship between stakeholders by creating social stability and gain license to operate from the community surrounds (Figure 5).

\section{Environment effects}

At the beginning of the program, PERTAMINA EP commits to plant mangroves gradually. PERTAMINA EP started to plant mangroves in 2014-today, we have rescued the critical land

Table 2: Mangrove Vegetation Inventory. through mangrove plantation, with the success ratio about 90\% based on Mangrove Forest Management Center (BPHM) research. The areas for the program of Green Belt Lubuk Kertang are Lubuk Kertang as the critical area about 8 hectares and 19.5 hectares in Paluh Tabuan Timur. [Details of indicators and results of Shannon Wienner Index for every indicator can see in these tables below

From Table 2 The highest Shannon Wienner Index ( $\left.\mathrm{H}^{\prime}\right)$ only remains in buffer level of Lubuk Kertang Main Zone 1,24 categorized as medium diversity. That shows that other zone has low diversity caused of unstable ecosystem, high ecology pressure, with low productivity. It makes sense, because to restore heavily damaged ecosystem requires a long period of time.

\begin{tabular}{|c|c|c|c|c|c|}
\hline \multirow{2}{*}{ No } & & & Vegetation Analysis & Buffer Level & Seeding Level \\
\hline \multirow{2}{*}{1} & Location & Zone Critera & \multicolumn{3}{|c|}{ Shannon Wienner Index (H') } \\
\hline \multirow{2}{*}{1} & Paluh Tabuhan Timur (19Ha) & Main Zone & 0,13 & 0 & 0,63 \\
\cline { 3 - 6 } & & Buffer Zone & 0,08 & 0,4 & 0,56 \\
\cline { 3 - 6 } & & Used Zone & 0,2 & 0,9 & 1,03 \\
\hline
\end{tabular}




\section{Recent Advances in Petrochemical Science}

\begin{tabular}{|c|c|c|c|c|c|}
\hline \multirow{2}{*}{2} & \multirow{4}{*}{2} & Main Zone & 1,9 & 1,24 & 0,8 \\
\cline { 3 - 5 } & \multirow{2}{*}{ Lubuk Kertang (8Ha) } & Buffer Zone & - & - & - \\
\cline { 3 - 5 } & & Used Zone & - & - & - \\
\hline
\end{tabular}

Table 3: Insects Inventory.

\begin{tabular}{|c|c|c|c|c|}
\hline No & Location & Number of Ordo & Number of Famili & Shannon Wienner Index (H') \\
\hline 1 & Paluh Tabuhan Timur (19Ha) & 7 & 16 & 2,48 \\
\hline 2 & Lubuk Kertang (8Ha) & 8 & 26 & 3,02 \\
\hline
\end{tabular}

On the other hands, from Table 3 the Shannon Wienner Index $\left(\mathrm{H}^{\prime}\right)$ for insects inventory shows that Paluh Tabuhan Timur and Lubuk Kertang has a good environmental hygiene. Because the 2,48 and 3,02 categorized as high diversity and the diversity of insects is a positive bioindicator for potential ecosystem.
Table 4, shows that some species are classified in endanger status and by managing a good coastal management program and conserve their habitat may help these species to evolve. The endanger animals are Otter (Enhydra lutris), Black Stork (Ciconia episcopus), Long-tail Monkey (Macaca fascicularis), Falcon (Haliastur indus), and Gull (Tringa hypoleucos).

Table 4: Reptile and Aves Inventory.

\begin{tabular}{|c|c|c|c|c|c|}
\hline No & Location & Observati on Time & Number of Species & Clasification Status & Shannon Wienner Index (H') \\
\hline 1 & Paluh Tabuhan Timur & Day & 7 & Normal & 1,40 \\
\hline & & & 2 & Endanger & 1,48 \\
\hline & & Night & 8 & Normal & \\
\hline & & 18 & Endanger & 1,58 \\
\hline 2 & Total Species & Day & 6 & Normal & \\
\hline & & & 3 & Endanger & 0,61 \\
\hline & & Night & 5 & Species & \\
\hline & Total Species & $\mathbf{1 4}$ & & & \\
\hline
\end{tabular}

Table 5: Life below water inventory.

\begin{tabular}{|c|c|c|c|}
\hline No & Location & $\begin{array}{c}\text { Number of } \\
\text { Species }\end{array}$ & $\begin{array}{c}\text { Shannon Wienner } \\
\text { Index (H') }\end{array}$ \\
\hline 1 & Paluh Tabuhan Timur & 12 & 0,62 \\
\hline 2 & Lubuk Kertang & 24 & 0,74 \\
\hline
\end{tabular}

Table 5 shows that low categorization of Shannon Wienner Index in both places. The damaged caused by deforestation in mangroves land also give high impact for the life below water. There is an increasing number for mangrove biodiversity in conservation area in Table 6. Though is still in small number but the environment keep improving and evolving. In 2016, we observed that the mangrove biodiversity has increased from 2013 to 2016. In Paluh Tabuhan Timur, biodiversity index increased from 3.173 to 3.95. It also happens in Lubuk Kertang, it increased from 3.173 to 3.98 in 2016. Another impatcs by implementing this program is reduction of carbon $\left(\mathrm{CO}_{2}\right)$ emission from mangroves zone with total 16, 119 ton / Ha eq.
Table 6: Mangrove Conservation Area.

\begin{tabular}{|c|c|c|c|}
\hline No & $\begin{array}{c}\text { Years of } \\
\text { Observation }\end{array}$ & \multicolumn{2}{|c|}{ Biodiversity Index } \\
\hline & & Paluh Tabuhan Timur & Lubuk Kertang \\
\hline 1 & 2012 & 3,173 & 3,173 \\
\hline 2 & 2013 & 3,173 & 3,173 \\
\hline 3 & 2014 & 3,607 & 3,607 \\
\hline 4 & 2015 & 3,902 & 3,902 \\
\hline 5 & 2016 & 3,949 & 3,980 \\
\hline
\end{tabular}

\section{Economic effects}

Since the implementation of development Edco-tourism program in the beginning of 2017 to April not less than 1000 visitors came to the site. From the retribution, at least IDR $15,000,000 /$ month become the earning of MEKAR's group. This condition also contributes to increase the income of every member from IDR 300,000 to IDR $1,000,000 /$ month. The graphics below are the recordable data from Edco-tourism management. (Figure 6) 


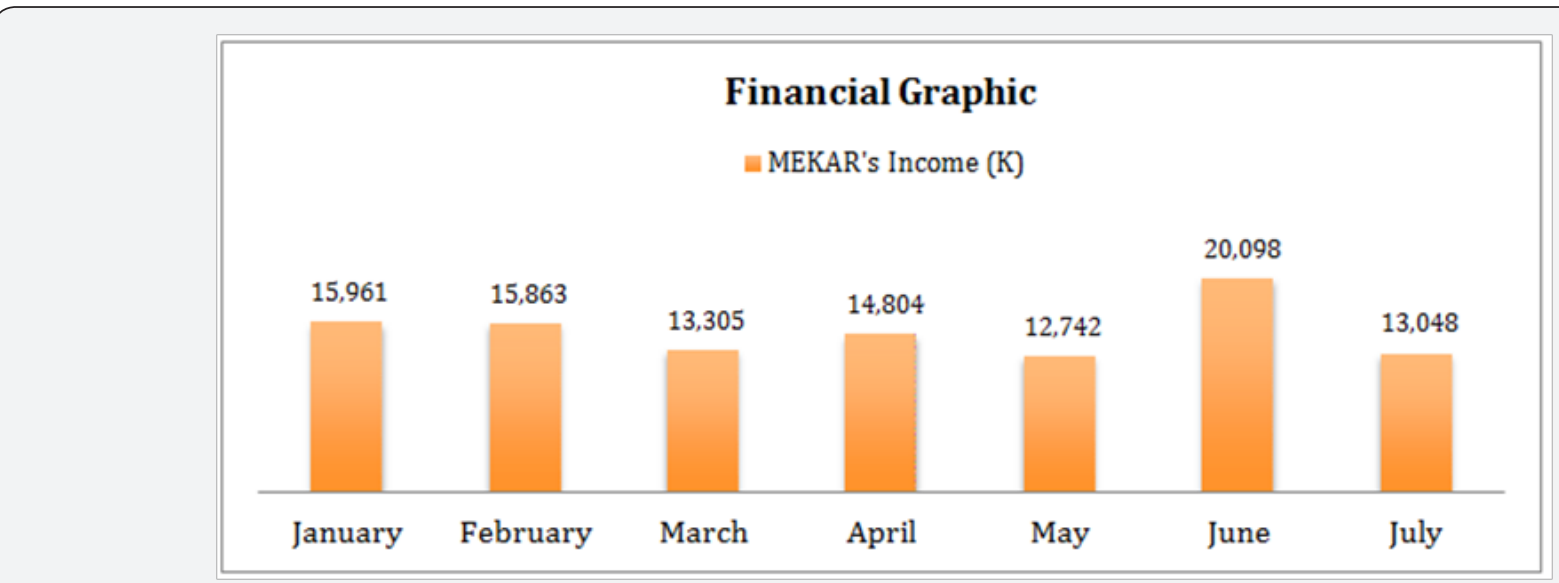

Figure 6: Financial Graphic.

\section{Social effects}

Not only services but also program evaluation are needed to create a sustainable development of coastal management. Using Public Satisfaction Index (IKM) PERTAMINA EP try to elaborate with public expectation about the company.

From Table 7 above, the category level of the program 'Good' means that there are so many room of improvement. Edco-tourism is a tourism concept that may combine between education and nature (eco) friendly tourism. This concept is not only to promote mangroves tourism; but also to make positive and direct contribution between visitors and the local community. Other social effect is the increasing number of MEKAR's member. Starting with only 2 members in 2012 now MEKAR has grown to 45 members. Through social media optimization, in 2017, Lubuk Kertang Mangroves Conservation Area is one of the tourist destinations in Langkat and becomes research centre for studies from domestic and international institutions. This mangroves area has also been published on National Geographic Indonesia in September 2016. The program "Green Belt Lubuk Kertang" was awarded Indonesia Green Awards in 2015, 2016 and 2017 for conservation biodiversity categories.

Table 7: Public Satisfaction Index of Green Belt Lubuk Kertang Program.

\begin{tabular}{|c|c|c|c|}
\hline No. & Criteria & Aspects Value & Category Level \\
\hline 1 & Company's commitment & 3,4 & Good \\
\hline 2 & Society contribution & 4,00 & Excellent \\
\hline 3 & Program relevance & 3,4 & Good \\
\hline 4 & Program sustainability & 2,35 & Good \\
\hline 5 & Plan and implementation program & 3,5 & Excellent \\
\hline 6 & Company's response & 3,5 & Excellent \\
\hline 7 & $\begin{array}{l}\text { Clarity and fairness in program } \\
\text { implementation }\end{array}$ & 3,4 & Excellent \\
\hline 8 & Officer resposibility & 3,75 & Excellent \\
\hline 9 & Officer capacity & 2,4 & Good \\
\hline 10 & Officer acceptance by society & 4,00 & Excellent \\
\hline 11 & Budget & 2,9 & Good \\
\hline 12 & $\begin{array}{l}\text { Company's relationship with } \\
\text { stakeholders }\end{array}$ & 2,39 & Poor \\
\hline 13 & Scope of program & 3,3 & Excellent \\
\hline \multirow[t]{2}{*}{14} & Program benefit & 2,8 & Excellent \\
\hline & Total & 44,8 & \\
\hline Respondence & & & 20 \\
\hline Index value & & & 3,18 \\
\hline Conversion index value & & & 79.52 \\
\hline Quality level & & & B \\
\hline Category level & & & Good \\
\hline
\end{tabular}




\section{Conclusion}

The focus of this paper will be on how PERTAMINA EP encourages the community's local potential to confirming their business sustainability around our main working areas of operation. Though, this program has not giving a massive impact yet but it has shown that commitment of companycommunity relationship is mutual. The relationship develops into social establishment and license to operate for the company. Value creating through CSR program may help not only nature preservation but also reduce negative reputation from the community. It is about making the company has humanism point of view by take social responsibility seriously into the business process [14].

As for the community and mangroves area, the results are:

a) $\mathrm{CO}_{2}$ emission reduction from mangroves zone with total 16,119 ton/Ha eq.

b) Evolving the diversity around mangroves conservation area.

c) Help to prevent the conversion of $27 \mathrm{ha}$ of mangrove forests into oil palm plantations and illegal logging (deforestation).

d) Reducing 15\% of Methane from Green House Effect for mangroves planting and seeding.

e) Increasing number of community empowerment in tourism activities.

f) Income of beneficiary members increasing for almost $70 \%$ since managing mangroves edco- tourism program.

g) Help to prevent Langkat's Coast from abrasion for Mangrove Cultivation Program.

h) Enlarging social engagement and coastal education for the community.

\section{Acknowledgement}

This study and strategy was supported and funded by PT PERTAMINA EP Asset 1 Pangkalan Susu Field. By implementing the program based on this study, PERTAMINA EP has awarded for GREEN PROPER since 2014 held by Ministry of Environment and Forestry Indonesia.

\section{References}

1. Data Source: Ministry of Fisher and Marine

2. Giri C, Ochieng E, Tieszen LL, Zhu Z, Singh A, et al. (2011) Global Ecology and Biogeography: Status and Distribution of Mangrove Forests of The World Using Earth Observation Satellite Data. A journal of macroecology 20(1): 154-159.

3. Schaeffer-Novelli Y, Soriano-Sierra EJ, do Vale CC, Bernini E, Rovai AC, et al. (2005) Climate Changers in Mangrove Forests and Salt Marshes. Brazilian Journal of Oceanography 64(2): 37-52.

4. Campbell A, Brown B (2015) Indonesia's vast mangroves are a treasure worth saving. The Conversation, Australia.

5. Murdiyarso D, Purbopuspito J, Kauffman JB, Warren M, Sasmito S, et al (2015) the potential of Indonesian mangrove forests for global climate change mitigation. Nature Climate Change 5: 1089-1092.

6. Ministry of Environment Republic of Indonesia (2010) Indonesia second national communication under the United Nations Framework Convention on Climate Change. Jakarta.

7. Pertamina EP (2015) PT Pertamina EP Asset 1 Pangkalan Susu Field Tajak Sumur Benggala (BGL) - 03. Social Mapping Document: Desa Lubuk Kertang. Langkat, Indonesian.

8. UNEP (2014) the Importance of Mangrves to People: A Call to Action. United Nations Environment Programme World Conservation Monitoring Centre, Cambridge, USA.

9. (2001) European Commissin: Promoting a European Framework for Corporate Social Responsibility. Green Paper, p. 8.

10. Luetkenhorst, W (2004) Corporate Social Responsibility and the Development Agenda. Intereconomics 39(3): 157-166.

11. Porter ME, Kramer MR (2006) Strategy \& Society-The Link between Competitive Advantage and Corporate Social Responsibility. Harvard Business Review 84(12): 78-92.

12. Twelvetrees A (1991) Community Work. In: $\left(2^{\text {nd }}\right.$ edn $)$, Macmillan, London, USA.

13. Monitoring report of biodiversity index (2016) PT Pertamina EP Asset 1 Pangkalan Susu Field.

14. Strategy Plan of CSR Document (2016) PT Pertamina EP Asset 1 Pangkalan Susu Field.

\section{Your next submission with Juniper Publishers will reach you the below assets}

- Quality Editorial service

- Swift Peer Review

- Reprints availability

- E-prints Service

- Manuscript Podcast for convenient understanding

- Global attainment for your research

- Manuscript accessibility in different formats

( Pdf, E-pub, Full Text, Audio)

- Unceasing customer service

Track the below URL for one-step submission https://juniperpublishers.com/online-submission.php 